Alaska Division of Geological \& Geophysical Surveys

RAW-DATA FILE 2013-3

HIGH-RESOLUTION LIDAR DATA FOR THE WHITTIER AREA, PASSAGE CANAL, AND PORTAGE LAKE, ALASKA

by

T.D. Hubbard, G.J. Wolken, D.S. P. Stevens, and R.A. Combellick

April 2013

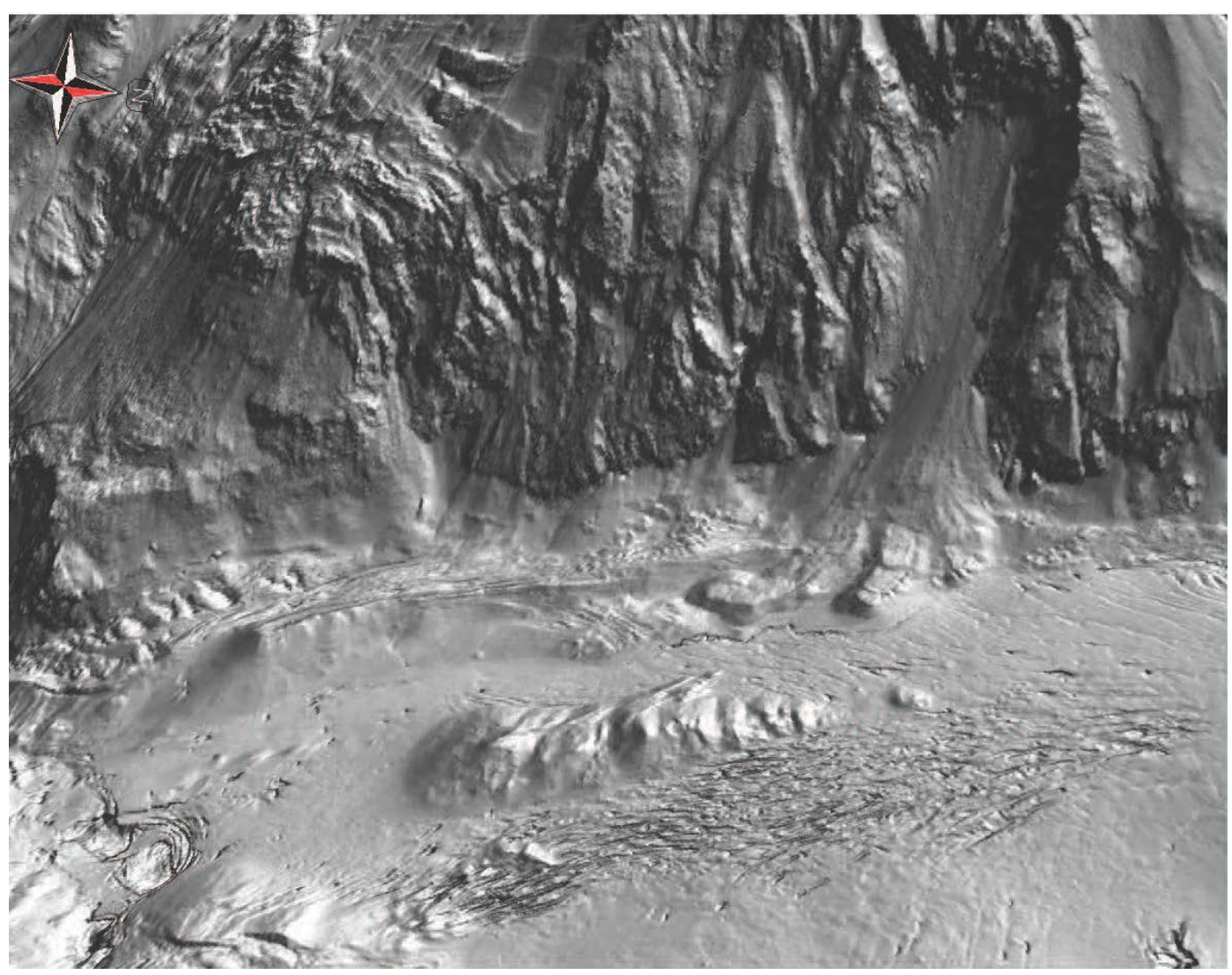

THIS REPORT HAS NOT BEEN REVIEWED FOR TECHNICAL CONTENT

OR FOR CONFORMITY TO THE EDITORIAL STANDARDS OF DGGS

Released by:

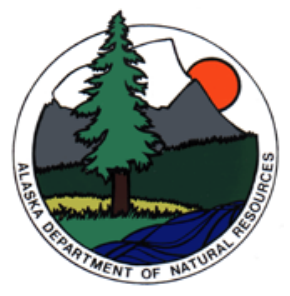

STATE OF ALASKA

DEPARTMENT OF NATURAL RESOURCES

Division of Geological \& Geophysical Surveys

3354 College Road, Fairbanks, Alaska 99709-3707

Email: dggspubs@alaska.gov

Website: www.dggs.alaska.gov
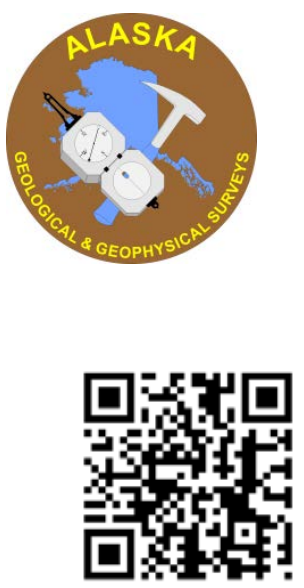



\section{CONTENTS}

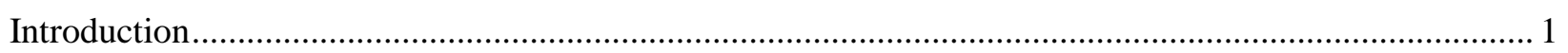

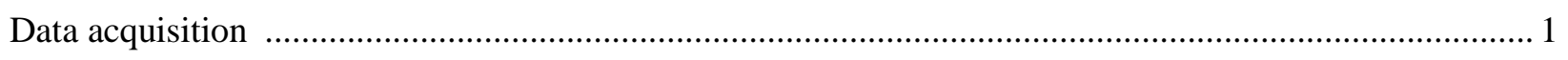

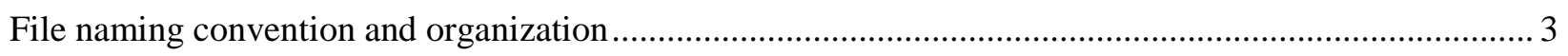

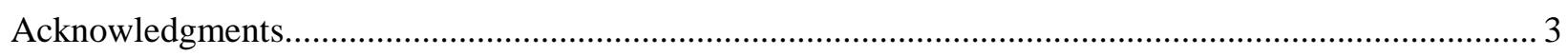

\section{FIGURES}

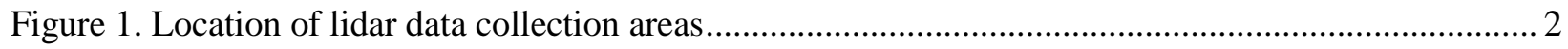

\section{TABLES}

Table 1. Abbreviations used in file names to designate different data types

Cover Image: Oblique lidar hillshade image showing landslide debris deposited on the surface of Learnard Glacier

Note: This report, including all digital lidar data, explanations, and tables, is available in digital format from the DGGS website (www.dggs.alaska.gov) for free download. 


\title{
HIGH-RESOLUTION LIDAR DATA FOR THE WHITTIER AREA, PASSAGE CANAL, AND PORTAGE LAKE, ALASKA
}

\author{
by \\ T.D. Hubbard ${ }^{1}$, G.J. Wolken ${ }^{1}$, D.S.P. Stevens ${ }^{1}$, and R.A. Combellick ${ }^{1}$
}

April 2013

\section{Introduction}

In support of geologic mapping and hazards evaluation in and near Whittier, Alaska, the Division of Geological \& Geophysical Surveys (DGGS) acquired, and is making publicly available, lidar (light detection and ranging) data for an area along Passage Canal, Portage Lake, and Portage Glacier Highway (fig.1). Data will serve multiple purposes but were primarily collected to map geology and evaluate potential geologic hazards. Steep slopes with poor access, combined with dense vegetation and a thick moss ground-cover that obscures the bedrock surface, make the use of lidar one of the most effective ways to map the geology and evaluate unstable slopes and other hazards.

\section{Data acquisition}

Lidar data, acquired and processed by Watershed Sciences, Inc. (WSI) consist of continuous coverage of approximately $50 \mathrm{mi}^{2}\left(\sim 130 \mathrm{~km}^{2}\right)$ encompassing an area extending from Portage Lake eastward to Logging Company Bay in Passage Canal in the Seward D-4, D-5, and D-6 1:63,360-scale quadrangles (fig. 1). Lidar data collected below 1,600 ft (488 m) elevation have a minimum average pulse density of 8 pulses $/ \mathrm{m}^{2}$ to penetrate the thick vegetation cover; above $1,600 \mathrm{ft}(488 \mathrm{~m})$, where vegetation is generally less dense, data were collected with an average pulse density of at least 4 pulses $/ \mathrm{m}^{2}$.

Following lidar data collection and processing by WSI and their survey subcontractor, McClintock Land Associates, WSI submitted the data to the State of Oregon Department of Geology and Mineral Industries (DOGAMI) for independent quality control analysis. After addressing any concerns from DOGAMI, WSI submitted the revised data set to DGGS along with a technical report describing details about the lidar acquisition, accuracy, and quality. DOGAMI also provided a separate report summarizing their methodologies and the results of quality control checks. Both reports are available via the DGGS website, http://www.dggs.alaska.gov/pubs/id/24976.

\footnotetext{
1 Alaska Division of Geological \& Geophysical Surveys, 3354 College Rd., Fairbanks, Alaska 99709-3707; trent.hubbard@alaska.gov, 907-451-5009
} 


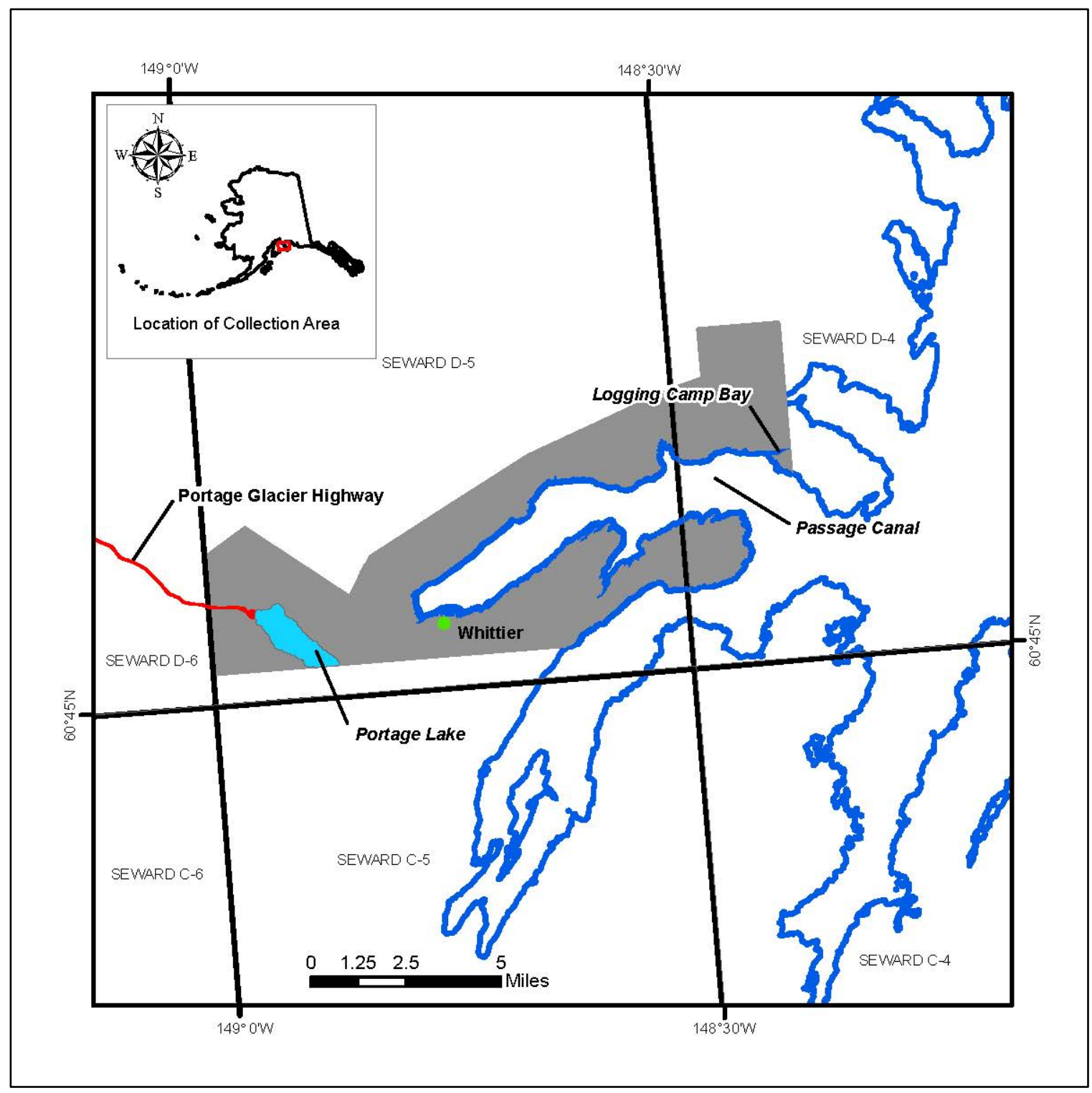

Figure 1. Map of study area; lidar data collection area shown by gray shading. 


\section{File Naming Convention and Organization}

DGGS organizes its lidar data download packages by 1:250,000-scale quadrangle. The Whittier lidar package includes data for a portion of the Seward Quadrangle. The names of geospatial data files (tiles) in each download package identify both the lidar data type and name of the 1:250:000-scale or, where applicable, the 1:63,360-scale quadrangle in which the data are located. The general format for file names is $x \_y$ where $x$ is the data type abbreviation and $y$ is the abbreviated quadrangle name. Table 1 lists the abbreviations used for each available data type. Quadrangle abbreviations follow USGS standards.

\begin{tabular}{|l|c|}
\hline \multicolumn{1}{|c|}{ Data type } & Data type abbreviation (x) \\
\hline Bare-earth digital elevation model (DEM) & be \\
\hline Bare-earth DEM hillshade image & in \\
\hline Lidar intensity image & hh \\
\hline Highest-hit DEM & water \\
\hline $\begin{array}{l}\text { Hydro-flattened waterbody polygons } \\
\text { (includes lakes, canals and rivers) }\end{array}$ & veg \\
\hline Vegetation digital surface model (DSM) & wh \\
\hline
\end{tabular}

Table 1. Abbreviations used in file names to designate different data types.

File naming examples:

1. A file with the name "be_sewd4" is a bare-earth DEM for the Seward D-4 1:63,360-scale Quadrangle.

2. A file with the name "water_sew" includes data for hydro-flattened water bodies in the Seward 1:250,000-scale Quadrangle.

Point-cloud data (all returns and ground-classified returns) are available for order from DGGS. Contact our staff at dggsgis@alaska.gov for more information.

In addition to the above data files, DGGS is also providing index files, available for free download, showing the location of LAS (point-cloud data), vector, and raster files.

\section{Acknowledgments}

Financial support for this work came from State of Alaska capital-project funding. The authors are grateful for support from several staff members of the Division of Geological \& Geophysical Surveys. Jim Weakland helped process data and create the hillshade images; Lauren Southerland helped organize the data for distribution; Susan Seitz created the programming by which the data are offered online; Simone Montayne assisted with metadata; and Ken Woods manages data on the server. 